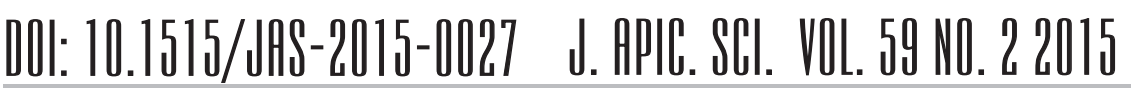

Original Article

\section{THE ABILITY OF HONEY BEE DRONES TO EJACULATE}

\author{
Krystyna Czekońska ${ }^{1 *}$ \\ Bożena Chuda-Mickiewicz ${ }^{2}$ \\ ${ }^{1}$ Department of Pomology and Apiculture, Agricultural University, \\ 29 Listopada 54, 31-425 Kraków, Poland \\ 2 Department of Zoology and Apiculture, West Pomeranian University of Technology, \\ Doktora Judyma 20, 71-466 Szczecin, Poland
}

*corresponding author: k.czekonska@ogr.ur.krakow.pl

Received 24 July 2015; accepted 07 October 2015

A b s t ract

The effectiveness of two methods of collecting semen from honeybee Apis mellifera drones was compared, and the reasons for problems with ejaculating semen were analysed. Among 275 drones, 100 were stimulated to release semen using a manual method, 100 with the use of chloroform, and from 75 drones the reproductive organs were dissected for analysis and evaluation. It was found that the principal causes of problems that drones had with ejaculating their semen were anatomical changes or a delay in the development of the mucus glands. It was also found that the method employing chloroform was less efficient in the first phase of eversion of the endophallus, compared with the manual method. The method with the use of chloroform allows the determination of the proportion of drones, which do not evert the endophallus because of poor or delayed development of mucus glands, as well as the proportion of drones which evert the organ, but do not ejaculate semen because of the absence of semen in the seminal vesicles.

Keywords: Apis mellifera, drone, eversion, reproductive organ.

\section{INTRODUCTION}

In a honeybee colony drones are responsible for producing semen and transmitting it to the queen during copulation. In drones, the spermatozoa are produced in the pre-imago stage of development. In the first days of a drone's life the spermatozoa are moved from the testes to the seminal vesicles, where they are stored until mating. Immediately after emerging from the cells, drones are not able to copulate. They reach the ability to mate in $9-12$ days after emergence (Bishop, 1920; Ruttner and Tryasko, 1976). Drones mate with the queen at the age of 15 - 23 days, the average being 21 days (Couvillon et al., 2010). Because of the limited number of young queens, only a few drones have the chance to pass on their semen during copulation. The majority of drones die because of age, diseases, or predators (Free and Williams, 1975; Fukuda and Ohtani, 1977; Rueppell et al., 2005; Boes, 2010). A drone does not survive copulation (Witherell, 1965). On average, the drones that do not have the chance to copulate with a queen live 30 days (Rueppell et al., 2005).

Colonies differ in terms of the number of drones reared and their reproductive activity (Kraus et al., 2003; Boes, 2010). The reproductive success of drones depends much on the size of the colony and the conditions prevailing during rearing and maturing (Jaycox, 1961; Boes, 2010; Bieńkowska et al., 2011; Mazeed, 2011; Abdelkader et al.; 2014). The drones reared in larger colonies achieve greater reproductive success; more often copulate with the queen, and also have a larger share in the number of offspring (Kraus et al., 2003). The drones reared under optimum thermal and feeding conditions have greater chance of mating (Jaycox, 1961; Rueppell et al., 2006; Czekońska et al., 2013). Drones reared in colonies of different quality, differ in the age when they reach the ability to copulate with the queen (Rhodes et al., 2011; Czekońska et al., 2015). Therefore, in practice, the age of drones is not the correct indicator of their sexual maturity (Kurennoi, 1953; Drescher, 1976; Rhodes et al., 2011). This is confirmed by the differences in the number of drones needed to collect one dose of semen for the artificial insemination of the queen, as indicated by many authors (Chuda-Mickiewicz and Prabucki, 1993; Woyke, 2008; 2010; Rhodes et al., 2011; Czekońska et al., 2015). 
It is recommended that the queens should be artificially inseminated with semen from drones which are 10 - 28 days old (Woyke and Jasiński, 1978; Harbo, 1986; Cobey et al., 2013). Using various methods, the drones in this age range can be provoked to evert the endophallus and release semen (Witherell, 1965; Laidlaw, 1977). In practice, though, it is chiefly the manual method that is applied (Mackensen and Ruttner, 1976; Cobey et al., 2013). In its first phase, the method involves squeezing the thorax of the drone or rolling it lightly, at the same time keeping its abdomen upwards. As the result of pressure, the contraction of the abdominal muscles occurs followed by the partial eversion of the endophallus. When the abdomen remains soft, or the cornua is not yellow-orange in colour, it indicates that the drone is not mature and will not yield semen. In the second phase, the full eversion of the endophallus is obtained by gradual pressure applied to the sides of the abdomen, beginning from the anterior segment towards the end of the abdomen.

Apart from the above-described manual method, there is also another way to evaluate sexual maturation or to obtain semen. This method involves provoking the drone to release semen by subjecting it to the action of chloroform. After the partial eversion of the endophallus, the full eversion is obtained by gradual pressure applied to the sides of the abdomen, like in the manual method (Mackensen and Ruttner, 1976; Laidlaw, 1977; Stürup et al., 2013). The effectiveness of chloroform compared with the manual method is not known. Either method can have great measurement error. In the case of using chloroform, the error may result from the application method or dose. In the case of the manual method, it is indicated that the measurement error reflects the level of experience of the person performing the evaluation (Cobey et al., 2013). The choice of a suitable method, however, can have an impact on the evaluation of the quality of drones, and their usefulness for the purpose of artificial insemination. The eversion and ejaculation success of drones depends largely on the skill and experience of the operator.

The difficulty in the eversion of the endophallus and ejaculation of semen are usually explained by the drones being too immature to copulate (Mindt, 1962; Tozetto, 1997; Rhodes et al., 2011). The problems with ejaculating semen may also be caused by anatomical abnormalities or physiological disorders, which often stem from poor rearing conditions or from the existence of diseases, including the presence of Varroa destructor (De Jong, 1997; Duay et al., 2002; 2003; Retschnig et al., 2014), and viral diseases (Fievet et al., 2006; Cruz-Landim et al., 2012).

The objective of this study was to compare the effectiveness of two methods of collecting semen from drones, and to analyse the causes of the problems associated with the eversion of the endophallus and the ejaculation of semen.

\section{MATERIAL AND METHODS}

Honey bee (Apis mellifera carnica) drones were reared in two colonies with a two-year old, naturally inseminated queen. Colonies numbering c. 40 thousand worker bees were kept in Wielkopolski-type hives with $360 \times 260 \mathrm{~mm}$ frames. Each colony occupied two ten-frame chambers, separated from each other by a queen-excluder (11 worker combs filled with brood in all stages of development, 8 combs with food, 1 experimental drone comb). The rearing of drones started from transferring the queen to the drone comb, placed in an isolator made of a queen-excluder, in the brood chamber. After $24 \mathrm{hrs}$, the queen was released from the isolator, while the comb with eggs was transferred to the top chamber. The top chamber was separated from the brood chamber, so that the queen was not able to lay eggs on it. In the top chamber, the drone comb was placed between combs with brood ready to emerge. On the $23^{\text {rd }}$ day after the eggs were laid, the comb with drone brood was placed in an isolator made of a queen-excluder, allowing workers free access. The time of the emergence of drones was checked. Only the drones emerging within 24 hrs were included in the tests. The drones were kept in colonies until testing.

Drones, aged 15 days, all from one mother, were divided into three groups. The drones allocated to the first group, hereinafter referred to as SM, were excited to evert their endophalli and release semen with the use of the manual method described by Cobey et al. (2013). The drones in the second group, referred to as SC, were individually treated with chloroform for the partial eversion of the endophallus and then their abdomens were squeezed the same way as the drones in the SM group for full eversion and ejaculation (Mackensen and Ruttner, 1976). The drones allocated to the third group, referred to as $S$, after falling into a chill-coma, as a result of keeping them for 15 - 20 minutes at a temperature of $6^{\circ} \mathrm{C}$, were dissected and their reproductive organs were assessed (Dade, 1994; Carreck et al., 2013). The 
experiment was repeated twice. In the first replication, 133 drones (45 were dissected, 40 in group MS, and 48 in group SC) were examined. In the second replication, 142 drones (30 were dissected, 60 in group MS and 52 is SC) were examined. A total of 275 drones were examined, including 75 drones subjected to the dissection of their reproductive organs. For the other 200 drones, the ejaculation of semen was provoked using one of the two methods. The 200 drones were divided into two groups of 100 drones each. This means that 100 drones were subjected to the manual method and 100 drones were subjected to the method with use of chloroform.

The number of drones everting their endophallus and releasing semen was assessed. The volume of semen released was measured in each drone from the SM and SC groups. The reproductive organs of drones from the $S$ group were assessed on the basis of their colour, anatomical, and physiological changes. After dissecting the reproductive organs, the colour variation of the testes, seminal vesicles, and mucus glands was examined, assuming that in sexually mature individuals testes which lack sper- length of each microcapillary filled with semen was then measured and converted to volume; $14.3 \mathrm{~mm}$ length of a capillary was taken to equal $1 \mu \mathrm{L}$. The volume of semen was determined by measuring the semen column in the microcapillary with callipers. Semen volume was measured to $0.1 \mu \mathrm{L}$ accuracy.

The proportions of drones everting the endophallus and releasing semen in the two groups were compared using G test (Sokal and Rohlf, 2009). The differences in semen volumes were analysed using Student's t-test. Statistical analyses were performed using the Statistica 9 software package (StatSoft, 2010).

\section{RESULTS}

Statistical analysis showed no significant differences between colonies, allowing us to pool the data for each experimental group (SM, SC, and S).

In the group stimulated by chloroform (SC), the endophallus was everted by statistically significantly fewer drones $(n=75)$ than in the manually stimulated (SM) group ( $n=99)$ (Gadj = 30.657, $p<0.001)$ (Fig. 1). Among the drones which everted the endophallus,

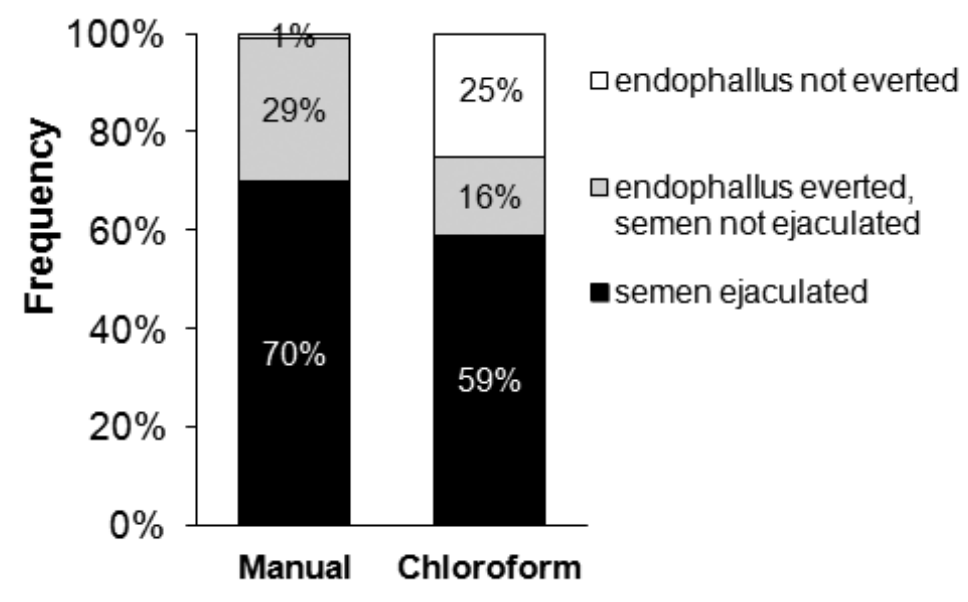

Fig. 1. Proportions of drones everting the endophallus and releasing semen as a result of manual or chloroform stimulation.

matozoa are greenish-yellow in colour, seminal vesicles filled with spermatozoa are yellow-orange, and mucus glands with mucus are milky-white, whereas those not filled with mucus are pearly white (Bishop, 1920; Snodgrass, 1956; Ruttner and Tryasko, 1976; Dade, 1994). In all the examined drones, the colour of the cornua was checked. It was assumed that in immature drones the cornua are transparent, whereas in mature drones they are orange (Koeniger et al., 1990).

Semen was collected in a calibrated microcapillary from each drone which everted its endophallus. The
59 drones in the SC group released semen, whereas 70 drones in the SM group. No statistically significant differences occurred between the SC and SM groups in the number of drones ejaculating semen $\left(G_{\text {adj }}=0.207, p=0.649\right)$.

The dissection of the reproductive organs of the 75 drones in group S, demonstrated that $29.0 \%$ of drones had anatomical or physiological changes in their mucus glands or seminal vesicles (Fig. 2). Of these, $24.0 \%$ had anatomical changes or underdeveloped mucus glands, and in $2.7 \%$ of drones, co-existing physiological changes of the seminal 


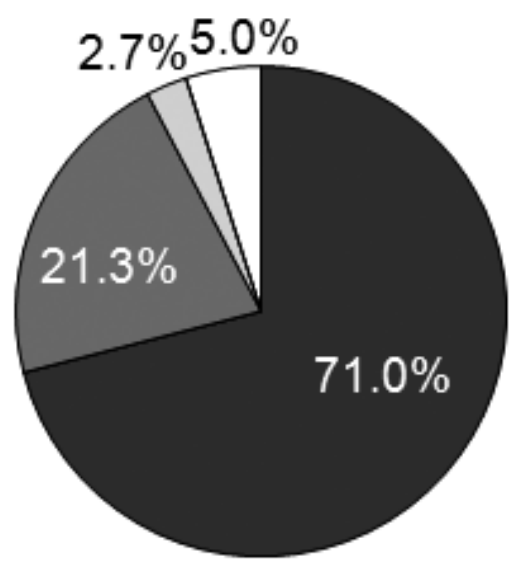

ano changes

口changes only in mucus glands

$\square$ changes in seminal vesicle and mucus glands

$\square$ changes only in seminal vesicle

Fig. 2. Proportions of drones considered capable of ejaculating semen, and the drones disqualified because of anatomical or physiological changes of the reproductive organs, determined on the basis of post-mortem examinations of their reproductive organs.

vesicles were found. The physiological changes of the seminal vesicles, as a sole feature, was found in an additional $5 \%$ of the drones. Regarding the mucus glands, their asymmetrical development and deformations were found in $14.6 \%$ of drones. The absence of mucus in the glands was observed in $2.7 \%$ of drones, whereas glands filled with mucus to a maximum of half-length were found in $6.7 \%$ of the drones. The drones with physiological changes of their seminal vesicles had, in $2.7 \%$ of the cases, one or both vesicles lacking cream-yellow collared semen, whereas the remaining $5 \%$ of drones had only slightly collared vesicles.

Because of the minute quantity of released semen, the measurements of semen volume were not performed in three drones from the SC group, and in one drone from the SM groups. On average ( \pm SD), the drones ejaculated $0.8 \pm 0.39 \mu \mathrm{L}$ of semen in the SC group, whereas in the SM group, the drones ejaculated $0.9 \pm 0.29 \mu \mathrm{L}$. No differences were found between the SC and SM groups in the quantity of semen released $(t=1.008, n=125, p=0.316)$ nor in the proportions of drones releasing semen in a volume exceeding $0.9 \mu \mathrm{L}\left(G_{\text {adj }}=1.237, p=0.266\right)$.

\section{DISCUSSION}

While testing the two methods of stimulating drones to ejaculate semen, differences were found only in the proportion of individuals everting the endophallus. The results showed that significantly less drones partly everted their endophallus when subjected to the chloroform treatment. No differences were found, however, between the proportions of drones ejaculating semen nor between the volumes of the semen ejaculated. Based on the results of post-mortem examinations, it was found that the anatomical changes or poor development of mucus glands were the chief reasons of problems with the release of semen. To a lesser degree, the dysfunctions of the seminal vesicles were responsible for these problems.

The post-mortem examination of the reproductive glands showed that the state of the mucus glands was principally responsible for deeming drones incapable of releasing semen. The proportion of drones with dysfunctions of the mucus glands (24\%) was quite similar to the proportion of drones of the SC group which did not evert the endophallus (25\%). The coincidence of these results gives ground for the presumption that the drones of the SC group, which did not evert the endophallus, also had immature or abnormally developed mucus glands. In general, the mucus glands mature with the age of the drones, and they reach full maturity between the 9th and the 12th day after emergence (Bishop, 1920; Woyke, 1958; Mindt, 1962; Cruz-Landim and Dallacqua, 2005; Moors et al., 2005). Our study demonstrated that not all drones reach their full development within this time range. The drones often differ in the stage of mucus gland development even 15 days after their emergence (Gençer and Firatli, 2005; Mazeed and Mohanny, 2010; Czekońska et al., 2013).

The secretion of the mucus glands plays an important role during the transfer of sperm to the reproductive tract of the queen (Bishop, 1920; Colonello and Hartfelder, 2005; Woyke, 2008; 2010; Koeniger 
et al., 2011). Cruz-Landim and Dallacqua (2005) reported that the production of mucus ends prior to the sexual maturity of drones. Our results indicate that the completion of mucus production enables the eversion of the endophallus. These indications were confirmed by the resemblance of the SM and $S$ group results, concerning the proportion of drones which released semen, or were deemed as capable of releasing semen. Such correspondence was not found in the case of the group of drones stimulated by chloroform. In this group the number of drones everting the endophallus was significantly lower. In the SC group, an additional, clear distinction was made between the drones which did not evert the endophallus, and those which although everting the endophallus did not ejaculate. In the SC group, the high proportion (25\%) of drones which did not evert the endophallus corresponded with that proportion in the group having their reproductive organs dissected (24\%) which were disqualified on account of immaturity and developmental abnormalities of the mucus glands. Such correspondence was not obtained between the SC group, and the S group of drones which everted the endophallus but did not release semen. This group of drones includes the individuals with seminal vesicles without or with a small quantity of spermatozoa but having functional mucus glands - which corresponds to $5.3 \%$ of drones from the $S$ group. It is more difficult to explain the reasons for the absence of semen in the remaining $10.7 \%$ of drones of the SC group. In the SC group, the higher proportion of drones which did not release semen was caused by their incomplete readiness to release semen or - a reason which cannot be excluded - the adverse effect of chloroform on the drones.

\section{CONCLUSIONS}

In summary, the manual method allows the collection of semen from a greater number of drones compared with the method using stimulation by chloroform. However, the manual method permits only an estimation of the number of drones releasing and not releasing semen. The method employing stimulation by chloroform provides additional data on the drones, which did not evert the endophallus, because of developmental abnormalities or the delayed development of the mucus glands. This method also identifies the drones which everted the endophallus, but did not ejaculate semen because of the absence of semen in the seminal vesicles, or other likely causes not yet diagnosed.

\section{ACKNOWLEDGMENTS}

This work was financed by grants from MSHE, under the theme No. DS-3500 and DS-047.

\section{REFERENCES}

Abdelkader F. B., Kairo G., Tchamitchian S., Cousin M., Senechal J., Crauser D., Le Conte Y., Belzunces L. P." Barbouche N., Brunet J. L. (2014) Semen quality of honey bee drones maintained from emergence to sexual maturity under laboratory, semi-field and field conditions. Apidologie 45(2): 215-223. DOl: 10.1007/s13592-0130240-7

Bieńkowska M., Panasiuk B., Węgrzynowicz P., Gerula D. (2011) The effect of different thermal conditions on drone semen quality and number of spermatozoa entering the spermatheca of queen bee. Journal of Apiculture Science 55(2): 161-168.

Bishop G. H. (1920) Fertilization in the honeybee. I. The male sexual organs: their histological structure and physiological functioning. Journal of Experimental Zoology 31: 225-265.

Boes K. E. (2010) Honeybee colony drone production and maintenance in accordance with environmental factors: an interplay of queen and worker decisions. Insects Sociaux 57: 1-9. DOl: 10.1007/s00040-009-0046-9

Carreck N. L., Andree M., Brent C. S., Cox-Foster D., Dade H. A., Ellis J. D., Hatijina F., vanEnglesdorp D. (2013) Standard methods for Apis mellifera anatomy and dissection. Journal of Apiculture Research 52(4): 1 -40. D0l:10.3896/ IBRA. 1.52.4.03

Chuda-Mickiewicz B., Prabucki J. (1993) Próba określenia wpływu pory wychowu trutni na wartość inseminowanych matek. Pszczelnicze Zeszyty Naukowe 37: $41-49$.

Cobey S. W., Tarpy D. R., Woyke J. (2013) Standard methods for instrumental insemination of Apis mellifera queens. Journal of Apiculture Research 52(4): 1-18. DOl: 10.3896/IBRA.1.52.4.09

Colonello N. A., Hartfelder K. (2005) She's my girl - male accessory gland products and their function in the reproductive biology of social bees. Apidologie 36: 231 244. 
Couvillon M. J., Hughes W. O., Perez-Sato J. A., Martin S. J., Roy G. G., Ratnieks F. L. (2010) Sexual selection in honey bees: colony variation and the importance of size in male mating success. Behavioral Ecology 21(3): 520-525. DOl:10.1093/beheco/arq016

Cruz-Landim C. D., Dallacqua R. P. (2005) Morphology and protein patterns of honey bee drone accessory glands. Genetics and Molecular Research 4(3): 473-481. DOl: 10.1002/jemt.22024

Cruz-Landim D., Roat T. C., Fernadez F. C. (2012) Virus present in the reproductive tract of asymptomatic drones of honey bee (Apis mellifera L.), and possible infection of queen during mating. Microscopy research and technique 75(7): 986-990.

Czekońska K., Chuda-Mickiewicz B., Chorbiński P. (2013) The effect of brood incubation temperature on the reproductive value of honey bee (Apis mellifera). Journal of Apiculture Research 52: 96-105. D0l: 10.3896/ IBRA. 1.52.4.09

Czekońska K., Chuda-Mickiewicz B., Samborski J. (2015) Quality of honey bee drones reared in colonies with limited and unlimited access to pollen. Apidologie 46(1): 1-9. DOl: 10.1007/s13592-014-0296-2

Dade H. A. (1994) Dissection of the drone. In: Dade H. A. (Ed.) Anatomy and dissection of the honeybee. International Bee Research Association: 121-122.

De Jong D. (1997) Mites: Varroa and other parasites of brood. In: Morse R. A., Flottum K. (Eds.) Honey Bee Pests, Predators, and Diseases. A.I. Root Company. New York: 200-218.

Drescher W. (1976) Rearing and maintaining queens and drones. In: Ruttner F. (Ed.) The instrumental insemination of the queen bee. APIMONDIA, International Beekeeping Technology and Economy Institute. Bucharest: 25-38.

Duay P. R., De Jong D., Engels W. (2002) Decreased flight performance and sperm production in drones of the honey bee (Apis mellifera) slightly infested by Varroa destructor mites during pupal development. Cenetics and Molecular Research 1(3): 227-232.

Duay P. R., De Jong D., Engels W. (2003) Weight loss in drone pupae (Apis mellifera) multiply infested by Varroa destructor mites. Apidologie 34: 61-65.
Fievet J., Tentcheva D., Gauthier L., De Miranda J., Cousserans F., Colin M. E., Bergoin M. (2006) Localization of deformed wing virus infection in queen and drone Apis mellifera L. Virology Journal 3(16): 1-5. DOl: $10.1186 / 1743-422 X-3-16$

Free J. B., Williams I. H. (1975) Factors determining the rearing and rejection of drones by the honeybee colony. Animal Behaviour 23(3): 650-675.

Fukuda H., Ohtani T. (1977) Survival and life span of drone honeybees. Researches on Population Ecology 19: $51-68$.

Gençer H. V. Firatli C. (2005) Reproductive and morphological comparisons of drones reared in queenright and laying worker colonies. Journal of Apiculture Research 44(4): 163-167. DOl: 10.3896/IBRA. 1.44.4.06

Harbo J. R. (1986) Propagation and instrumental insemination. In: Rinderer T. E. (Ed.) Bee genetics and breeding. Academic Press. Orlando: 361-389.

Jaycox E. R. (1961) The effects of various foods and temperatures on sexual maturity of the drone honey bee (Apis mellifera). Annals of the Entomological Society of America 54(4): 519-52.

Koeniger G., Koeniger N., Phiancharoen M. (2011) Comparative reproductive biology of honeybees. In: Hepburn H. R., Radloff S. E. (Eds.) Honeybees of Asia. Springer-Verlag. Berlin Heidelberg: 159-206.

Koeniger G., Wissel M., Herth W. (1990) Cornual secretion on the endophallus of the honeybee drone (Apis mellifera L). Apidologie 21(3): 185-191.

Kraus F. B., Neumann P., Scharpenberg H., Van Praagh J., Moritz R. F. A. (2003) Male fitness of honeybee colonies (Apis mellifera L.). Evolutionary Biology 16(5): 914-920.

Kurennoi N. M. (1953) When are drones sexually mature? Pchelovodstvo 30(1 1): 28-32 [in Russian].

Laidlaw H. H. Jr. (1977) Instrumental insemination of honey bee queens. Dadant and Sons. Hamilton, IL, USA. 144 pp.

Mackensen O., Ruttner F. (1976) The insemination procedure. In: Ruttner $F$ (Ed.). The instrumental insemination of the queen bee. APIMONDIA, International Beekeeping Technology and Economy Institute. Bucharest: 69-86. 
Mazeed A. M. (2011) Morphometry and number of spermatozoa in drone honeybees (Hymenoptera: Apidae) reared under different conditions. European Journal of Entomology 108(4): 673-676. D01:10.14411/ eje.2011.085

Mazeed A. M., Mohanny K. M. (2010) Some reproductive characteristics of honeybee drones in relation to their ages. Entomological Research 40: 245-250. DOl: 10.1111/j.1748-5967.2010.00297.x

Mindt B. (1962) Untersuchung über das Leben der Drohnen, insbesondere Ernährung und Geschlechtsreife. Zeitscrift für Bienenforsch 6 (1): 9-33.

Moors L., Spaas O., Koeniger G., Billen J., (2005) Morfological and ultrastructural changes in the mucus glands of Apis mellifera drones during pupal development and sexual maturation. Apidologie 36: 245-254.

Retschnig G., Williams G. R., Mehmann M. M., Yañez O., De Miranda J. R., Neumann P. (2014) Sex-specific differences in pathogen susceptibility in honey bees (Apis mellifera). Plos One 9(1): e85261. D0l:10.1371/ journal.pone.0085261

Rhodes J. W., Harden S., Spooner-Hart R., Anderson D. L., Wheen G. (2011) Effects of age, season and genetics on semen and sperm production in Apis mellifera drones. Apidologie 42(1): 29-38. DOl: 10.1051/apido/2010026

Rueppell O.,FondrkM. K.,PageR. E.(2005)Biodemographic analysis of male honey bee mortality. Aging cell 4(1): 1319.

Rueppell O., Page R. E., Fondrk M. K. (2006) Male behavioural maturation rate responds to selection on pollen hoarding in honeybees. Animal Behaviour 71(1): 227-234. D0l:10.1016/j.anbehav.2005.05.008

Ruttner F. Tryasko V. V. (1976) Anatomy and Physiology of reproduction. In: Ruttner $F$. (Ed.). The Instrumental Insemination of Queen Bee. APIMONDIA, International
Beekeeping Technology and Economy Institute. Bucharest: 1 1-24.

Snodgrass R. E. (1956) Anatomy of the honey bee. Cornell University Press. Ithaca, New York. 352 pp.

Sokal R. R., Rohlf F. J. (2009) Biometry. W. H. Freeman and Company. New York. 363 pp.

StatSoft, Inc. (2010). Statistica, version 9.1. Available at: www.statsoft.com

Stürup M., Baer-Imhoof B., Nash D. R., Boomsma J. J., Baer B. (2013) When every sperm counts: factors affecting male fertility in the honeybee Apis mellifera. Behavioral Ecology 24(5): 1192-1198. DOl:10.1093/beheco/ art049

Tozetto S. D. O., Rachinsky A., Engels W. (1997) Juvenile hormone promotes flight activity in drones (Apis mellifera carnica). Apidologie 28(2): 77-84.

Witherell P. C. (1965) Survival of drones following eversion. Annales de l'Abeille 8(4): 317-320.

Woyke J. (1958) The histological structure of the reproductive organs of the drone. The Poznań Society of Friends of Science, Publication of the Section of Agriculture and Silviculture 19(2): 38-89.

Woyke J. (2008) Why the eversion of the endophallus of honey bee drone stops at the partly everted stage and significance of this. Apidologie 39(6): 627-636. DOl: 10.1051/apido:2008046

Woyke J. (2010) Three substances ejected by Apis mellifera drones from everted endophallus and during natural matings with queen bees. Apidologie 41 (6): 613 621. DOl: 10.1051/apido/20010007

Woyke J., Jasinski Z. (1978) Influence of age of drones on the results of instrumental insemination of honeybee queens. Apidologie 9(3): 203-212. 